\title{
Gönüllü Çocuksuzluk: Çocuk Sahibi Olmama Kararının Altında Yatan Faktörler ve Karşıllaşıllan Tepkiler Hakkında Bir Derleme
}

\section{Voluntary Childlessness: A Review of the Factors Underlying the Decision Not to Have Children}

\author{
Ezgi Sakman ${ }^{1}$ (i)
}

${ }^{1}$ Öğr. Gör., Bilkent Üniversitesi, İktisadi, İdari ve Sosyal Bilimler Fakültesi, Psikoloji Bölümü, Ankara, Türkiye

\section{ORCID: E.S. 0000-0002-5974-6566}

\section{Sorumlu yazar/Corresponding author:} Ezgi Sakman,

Bilkent Üniversitesi, İktisadi, İdari ve Sosyal Bilimler Fakültesi, Psikoloji Bölümü, 06800 Bilkent, Ankara, Türkiye

E-posta/E-mail: ezgi.sakman@bilkent.edu.tr

Başvuru/Submitted: 24.07.2020

Kabul/Accepted: 15.10 .2020

Online Yayın/Published Online: 22.02.2021

Citation/Atıf: Sakman, E. (2021). Gönüllü çocuksuzluk: Çocuk sahibi olmama kararının altında yatan faktörler ve karşılaşılan tepkiler hakkında bir derleme. Psikoloji Çalışmaları Studies in Psychology, 41(1): 83-109. https://doi.org/10.26650/SP2020-0105

\section{ÖZ}

Çocuk sahibi olmak her ne kadar uzun süreli romantik ilişkilerin (örn., evlilik) en önemli işlevlerinden biri olarak görülse ve evli çiftler arasında yaygın bir norm olsa da, son yıllarda hem dünyada hem de Türkiye'de doğum oranları giderek azalmaktadır. Çocuğu olmayan bazı kişiler, kısırlık gibi kontrolleri dışındaki durumsal nedenlerden değil, kendi iradeleri ile çocuksuz kalmaya karar vermektedir. Dünyada yaygınlığı giderek artan bu gönüllü çocuksuzluk kararı, bireyler için pek çok önemli psikolojik sonuç doğurmanın yanı sıra, toplumlar için de çok sayıda sosyolojik ve demografik etkiyi bünyesinde barındırmaktadır. Gönüllü çocuksuzluğun hem birey hem de toplum için giderek artan öneminden yola çıkılarak, bu derlemeyle bilinçli olarak çocuk sahibi olmama kararının sebeplerini ve sonuçlarını inceleyen çalışmaların sistematik bir biçimde taranarak Türkçe alan yazına kazandırılması amaçlanmıştır. Öncelikle, gönüllü çocuksuzluğu yordayan bireysel ve toplumsal faktörler ile bireylerin bu kararı almalarında rol oynayan etmenler ve karar süreçleri incelenmiş; daha sonra çocuksuz kalmaya karar veren bireylerin karşılaştıkları olumsuz kalıpyargıları ve bunlarla baş etme stratejilerini inceleyen çalışmalar taranmıştır. Derlenen çalışmaların sonuçları, her ne kadar bilinçli olarak çocuk sahibi olmamaya karar veren kişiler demografik olarak birbirlerine belli ölçüde benzese de, bu bireylerin bu kararı alma gerekçelerinin, mekanizmalarının ve kararları ile yaşama süreçlerinin hayli çeşitli olduğunu göstermektedir. Bunların yanı sıra gönüllü çocuksuzların, pek çok olumsuz kalıpyargıyla ve sosyal baskıyla karşılaşsalar da, yaşam doyumu ve psikolojik sağlık bakımından ebeveyn olan bireylere göre bir farklılık bildirmedikleri görülmektedir. Ayrıca yaygın kanının aksine, çocuksuz bireyler kararlarından pişman olmamaktadır. Son olarak, alan yazında gönüllü çocuksuzluk olgusunu inceleyecek ileriki çalışmaların yoğunlaşabileceği alanlar tartışılmış ve dikkate alınması gereken yöntemsel hususların altı çizilmiştir.

Anahtar Kelimeler: Gönüllü çocuksuzluk, çocuksuz kalma kararının sebepleri, gönüllü çocuksuzluğun sonuçları, çocuksuzluğa karşı olumsuz kalıpyargılar, üreme özgürlüğü 


\begin{abstract}
Although having children is seen as one of the most important functions of adult romantic relationships (e.g., marriage) and it is a common norm followed by married couples, birth rates both around the world and in Turkey have steadily declined over the past years. Some childless individuals have decided to remain childfree of their own volition and not due to external factors that lie outside of their control, such as infertility. This voluntary childlessness, which is becoming more and more prevalent around the world, not only has very important psychological consequences for individuals but will also have a significant sociological and demographic impact on societies. Building on the increasing importance of voluntary childlessness for both the individual and society, the present review systematically examines the studies that have investigated the reasons and consequences of the decision to remain childfree and introduce the issues to the Turkish literature. The first part of the review focuses on the individual and societal factors that can predict voluntary childlessness and examines the motivations that inform the decision mechanism. Second, studies investigating the negative stereotypes and societal pressures faced by people who decide to remain childfree and the coping strategies they adopt are reviewed. The results of the studies reviewed indicate that although individuals who consciously decide to remain childless demonstrate a degree of similarity in certain demographic characteristics, their reasons for their decision and the way they live with their choice show significant variation. In addition, although individuals who are voluntarily childless face serious stigma and societal pressure, they do not report any differences in life satisfaction and mental health to individuals who become parents. Also, contrary to common belief, childfree individuals do not regret their decision. At the end of the review, avenues for future research into voluntary childlessness are discussed, and methodological issues that need attention are underlined.
\end{abstract}

Keywords: Voluntary childlessness, reasons for remaining childfree, consequences of voluntary childlessness, negative stereotypes faced by the childfree, reproductive freedom

\title{
EXTENDED ABSTRACT
}

Although having children is still the widespread norm among long-term romantic partners and married couples, more and more people are deciding to opt-out of parenting. Voluntary childlessness (i.e., consciously deciding not to have or bear children) has important individual and societal consequences, therefore interest in research on this topic has increased over the past decades (e.g., Agrillo \& Nelini, 2008; Blackstone \& Stewart, 2012; Shapiro, 2014). Building on the growing importance of the issue, the present article reviews studies investigating the individual and societal factors predicting voluntary childlessness, the mechanisms behind this decision, and the stigma faced by the childfree.

The results of these studies indicate that remaining childfree is a complex social phenomenon shaped by various factors for different people (e.g., Agrillo \& Nelini, 2008; Blackstone \& Stewart, 2012). Although childfree people share several demographic characteristics, their reasons for deciding not to have children, their decision-making processes, and the strategies they employ to cope with the stigma they face show significant variation.

Individuals become more likely to remain childfree as their socioeconomic status improves (e.g., Abma \& Martinez, 2006; Somers, 1993), they participate in the workforce more, place a higher value on their careers (e.g., Cwikel, Gramotnev, \& Lee, 2006; Park, 2002), 
and also as they adopt more liberal and egalitarian worldviews (e.g., Avison \& Furnham, 2015; Burman \& de Anda, 1985). With work and similar intellectual activities offering alternative ways of leaving a legacy behind and achieving symbolic immortality, voluntary childlessness has become more and more prevalent in developed countries (Aarssen \& Altman, 2006). Ever improving birth control methods and reproductive technologies and the more liberal values that have been adopted in some societies may have also contributed to this phenomenon. The high likelihood of these factors continuing to rise in the coming years suggests that the number of childfree individuals might also surge. A potential increase in the number of people who remain without children is a critical matter that requires research and public policy attention as it will have serious repercussions for both population dynamics and the care of the elderly who will be childless.

Just like deciding to have children, deciding not to have them is a very personal choice that needs to be left to an individual's own volition. To ensure that individuals' rights to shape their own lives and children receive higher quality care from parents who really do want to become parents, societies should support individuals who do and do not decide to have children equally. This is a strategy that could potentially increase the welfare of a society through both women's and men's liberation and increased parenting quality.

Research on voluntary childlessness indicates that societies are far from this point. Individuals who decide to remain childfree endure serious stigma and societal pressure; they face pity and condescension, or sometimes even anger (e.g., Campbell, 1999; Mollen, 2006; Park, 2002; Somers, 1993). As a result, they either feel pressured to hide their true stance on the subject or feel they have to take an offensive position and argue that their choice not to parent is morally superior to having children (e.g., Gillespie, 2000; Park, 2002; Veevers, 1980). Patiently explaining that deciding not to have children is as normal a right as deciding to have them and that the childfree can still be well-functioning members of society might be helpful in slowly eradicating the negative stereotypes associated with childlessness. Despite this stigma and social pressure, the childfree are on a par with parents in terms of life satisfaction and psychological adjustment (e.g., Dykstra \& Keizer, 2009; McMullin \& Marshall, 1996; Wu \& Hart, 2002). Also, despite common belief, the voluntarily childless do not regret their decision (e.g., Brooks, 2019).

\section{Discussion}

A rich literature notwithstanding, research on voluntary childlessness still needs to address several important issues. Future studies should try and disentangle who consciously decides to remain childfree and who are childless due to circumstances outside of their control. Clarifying this distinction is important as several studies in the current literature 
have investigated childless adults as a single category, which leads to crucial differences between the childfree being missed. Also, more qualitative research is required to better understand the dynamics behind the decision to remain childfree, especially in terms of individual worldviews versus cultural values. Another important avenue for future research is how the childfree are organized as a social group and whether they will translate their collective action efforts to pursue equal rights with parents, especially in the labor market. Future studies should also investigate how a potential increase in the number of childfree adults could impact social demographics and public policies governing caregiving for children and the elderly. 
Dünyaya çocuk getirmek ve büyütmek, yetişkinlikteki uzun süreli romantik ilişkilerin (örn., evlilik) en önemli işlevlerinden biri olarak görülmektedir. Erken dönemde korunmasız insan yavrusunun, onu büyütecek ve yaşamsal destek verecek kişilerle gerekli fiziksel yakınlığı sağlamasını garantileyen bağlanma davranışsal sisteminin, çocuğun bakım verenleriyle sürekli ve güçlü bir duygusal bağ kurmasını ve böylece bu kişilerin çocuğun hayatta kalmasına yardım etmesini sağlamak üzere evrimleştiği ortaya atılmıştır (Bowlby, 1973, 1980, 1982). Bağlanma davranışsal sisteminin yetişkinlikte de romantik partnerlerin birbirine bağlanmasında ve uzun süreli yakın ilişkiler kurmasında rol aldığı öne sürülmüştür (Hazan ve Shaver, 1987). İnsan yavrusu uzun süre yüksek ebeveyn yatırımına ihtiyaç duyar, bu yüzden iki ebeveyni bir arada olan çocukların daha kaliteli bakım alarak hayatta kalma ve üreme yaşına kadar yaşama olasılıkları daha fazladır. Romantik partnerler arasında duygusal bağ kurulmasını sağlayan bağlanma davranışsal sisteminin en önemli işlevlerinden birinin partnerlerin bir arada kalmasını sağlayarak çocukların yaşama şansını artıran evrimsel bir adaptasyon olarak görev yapmak olduğu düşünülmektedir. Buna uygun olarak, çocuk sahibi olmak tarihsel olarak evliliğin temel amaçları arasında görülmüştür (Campbell, 1985) ve uzun süreli romantik ilişkisi olan veya evli çiftler arasında yaygın bir normdur. Bununla beraber, son yıllarda doğum oranlarının hem Türkiye'de (Türkiye İstatistik Kurumu, 2020) hem de dünyada (Sappleton, 2018) düşmekte olduğu gözlemlenmektedir. Çocuk sahibi olmayan kişilerin bazıları, kısırlık gibi kontrollerinde olmayan durumsal nedenlerden dolayı değil, kendi iradeleri ile çocuk yapmamaya karar vermektedir (bkz., Agrillo ve Nelini, 2008). Kişinin koşulları nedeniyle değil, kendi tercihi ile çocuk sahibi olmaması gönüllü çocuksuzluk olarak adlandırılmaktadır (Veevers, 1979).

Gönüllü çocuksuzluk, alan yazına görece yeni giren ve üzerinde araştırmaların giderek arttığı güncel bir kavramdır. Nüfus sayımları genellikle çocuğu olmayan bireylere kendi istekleriyle mi yoksa durumsal nedenlerden dolayı mı çocuksuz olduklarını sormadığı için gönüllü çocuksuzların toplumdaki oranını net olarak hesaplamak zordur. Ancak Amerika' da yapılan ulusal araştırmalar nüfusun ciddi bir oranının (\%5-6) kendini gönüllü çocuksuz olarak tanımladığını göstermektedir (Martinez, Daniels ve Chandra, 2012; Newport ve Wilke, 2013). Her ne kadar bilinçli olarak çocuksuz kalmaya karar vermek ilk bakışta uzun süreli romantik ilişkilerin (örn., evlilik) temel işlevine aykırı bir durum olarak görünse de, yapılan derleme çalışmaları kendini gönüllü çocuksuz olarak tanımlayan insanların oranının her geçen gün arttı̆̆ını göstermektedir (bkz., Agrillo ve 
Nelini, 2008; Blackstone ve Stewart, 2012; Shapiro, 2014). Tarihsel olarak çocuk sahibi olmamak hem doğum kontrolünün güçlüğü nedeniyle pratik açıdan zor, hem de çocuğun ekonomik değeri ve çocuk sahibi olma konusundaki sorgulanmayan toplumsal normlar nedeniyle istenmeyen bir durum olmuştur (bkz., Zelizer, 1985). Etkinliği ve yaygınlığı artan doğum kontrol yöntemleri, çocukların hem iş gücüne katkılarının hem de ileri yaşta ebeveyne bakım sağlama işlevlerinin azalması (bkz., Kagitcibasi ve Ataca, 2015), bazı toplumların liberal değerleri daha çok benimsemesi ve feminizm hareketleri ile birlikte çocuk sahibi olma oranlarında azalmalar görülmektedir. Dünyaya çocuk getirmemeye karar vermenin önemli pek çok bireysel ve psikolojik sonucu olduğu gibi, bu karar sosyolojik ve demografik pek çok etkiyi de beraberinde getirmektedir. Özellikle gönüllü çocuksuzların oranlarının artması devletlerin nüfus politikaları açısından büyük bir potansiyel etki barındırmaktadır.

Gönüllü çocuksuzluğun, hem teorik olarak açıklanması gerekliliği, hem de birey ve toplum için giderek artan önemi nedeniyle, bu derlemede bilinçli olarak çocuk sahibi olmama kararının sebeplerini ve sonuçlarını inceleyen araştırmaların sistematik olarak taranarak Türkçe alan yazına kazandırılması amaçlanmıştır. Bu tarama, yabanıı alan yazındaki derleme çalışmalar (örn., Blackstone ve Stewart, 2012) baz alınarak "voluntary childlessness (gönüllü çocuksuzluk)”, "childfree (çocuksuz)”, "childless-by-choice (kendi tercihiyle çocuksuz)", "voluntarily childless (gönüllü çocuksuz)" ve "remaining childless (çocuksuz olmaya devam etmek)" anahtar kelimeleri kullanılarak PsycInfo veri tabanında gerçekleştirilmiştir. Bu anahtar kelimelerin başlık, öz ve/veya anahtar kelimelerde aranması sonucunda 415 yayın listelenmiştir. Bu listede aynı yayının tekrar sıralandığı durumlar ve istemeyerek çocuksuz kalan (örn., infertilite nedeniyle) katılımcılarla yapılan çalışmalar elenerek 102 adet yayına ulaşılmış ve mevcut derlemede bu yayınlar incelenmiştir.

Bundan sonraki kısımlarda, önce gönüllü çocuksuzluğu yordayan faktörler, bireylerin bu kararı almalarında rol oynayan etmenler ve karar süreçlerini araştıran çalışmalar sistematik olarak taranmıştır. Daha sonra, gönüllü çocuksuzluğun sonuçlarını ve çocuksuz kalmaya karar veren bireylerin karşılaştıkları olumsuz kalıpyargıları ve bunlarla baş etme stratejilerini inceleyen araştırmalar derlenmiştir. Bilinçli bir şekilde çocuk sahibi olmama stratejisinin evrimsel açıdan incelenmesinin ardından, son olarak gönüllü çocuksuzluk olgusu üzerine yapılacak gelecek çalışmaların eğilebileceği alanlar tartışılarak dikkat edilmesi gereken yöntemsel hususların altı çizilmiştir. 


\section{Gönüllü Çocuksuzluğu Yordayan Demografik, Psikolojik ve Toplumsal Faktörler ile Bireylerin Karar Alma Süreçleri}

Bilinçli olarak çocuk sahibi olmamayı tercih eden bireylerde bazı demografik özellikler yaygın olarak görülmektedir. Kendini gönüllü çocuksuz olarak tanımlayan bireyler, diğer çocuksuz bireylere göre ortalama olarak yaşça daha büyüktür. Bu durum, genç yaştaki kişilerin hali hazırda çocukları olmasa bile ileride bir gün çocuk sahibi olabileceklerini düşünerek kendilerini gönüllü çocuksuz olarak tanımlamamalarıyla açıklanmaktadır (Heaton, Jacobson ve Holland, 1999; Kelly, 2009; Veevers, 1973a).

Gönüllü çocuksuzluk eğitim (Abma, Chandra, Mosher ve Peterson, 1998; Abma ve Martinez, 2006; Heaton ve ark., 1999; Keizer, Dykstra ve Jansen, 2008; Krishnan, 1993; Somers, 1993) ve gelir seviyesi (Abma ve Martinez, 2006; Bachu, 1999; Jacobson ve Heaton, 1991; Somers, 1993) yüksek bireylerde daha yaygındır. Bu bulgular, çocuk sahibi olmanın daha yüksek sosyoekonomik düzeydeki insanlar, özellikle de kadınlar için iş gücünden uzak kalmak ve kariyer yolunda zaman kaybetmek gibi sonuçları olduğu düşünüldüğünde daha yüksek firsat maliyeti içerdiğini düşündürmektedir. Bununla paralel olarak, bilinçli olarak çocuk sahibi olmamaya karar veren kadınların oran1, yüksek prestijli ve kariyer odaklı mesleklerde ve yönetici pozisyonlarında daha yüksektir (Bachu, 1999; Bram, 1984; Crispell, 1993; Cwikel, Gramotnev ve Lee, 2006; Park, 2002).

Sosyoekonomik faktörlerin yanı sıra çocuk sahibi olmama kararında çeşitli dünya görüşlerinin de önemli olduğu anlaşılmaktadır. Örneğin, gönüllü çocuksuz çiftlerin dindarlık düzeylerinin daha düşük olduğu rapor edilmiştir (Avison ve Furnham, 2015; Heaton, Jacobson ve Fu, 1992; Krishnan, 1993; Mosher, Williams ve Johnson, 1992). Kendini Hristiyan olarak tanımlayan kadınlarla yapılan bir nitel araştırmada katılımcılar, dini kimliklerinin bilinçli olarak çocuk sahibi olmama isteklerini engellediğini ve bu konuda konuşmaktan çekindiklerini rapor etmişlerdir (Llewellyn, 2016). Ayrıca gönüllü çocuksuzluk büyük şehirlerde (DeOllos ve Kapinus, 2002) ve liberal, bireyci ve eşitlikçi değerlere sahip bireyler arasında (Avison ve Furnham, 2015; Baber ve Dreyer, 1986; Bram, 1984; Burman ve de Anda, 1985) daha yaygındır. Benzer şekilde, çocuk sahibi olmamaya karar veren bireyler geleneksel aile modeline ve doğumu teşvik eden politikalara daha az destek vermektedir (Majumdar, 2004; Seccombe, 1991). Ayrıca çocuksuz kalmayı seçen çiftlerin daha eşitlikçi ilişkileri olduğu bulunurken (Ireland, 1993; McAllister ve Clarke, 1998a; Morell, 1994), çocuğu olmayan kadınların anne olan kadınlara 
göre toplumsal cinsiyet rolleri ile ilgili daha eşitlikçi değerlere sahip oldukları da gözlemlenmiş̧ir (Abma ve Martinez, 2006). Çocuk sahibi olmama kararı almanın liberal ve özgürlükçü değerler benimsemiş bireyler arasında daha yaygın olduğunu gösteren bütün bu bulgular, gönüllü çocuksuzluğun toplumların muhafazakar kesimlerinde daha az kabul görebileceğini düşündürmektedir.

Kişilerin bilinçli bir şekilde çocuk sahibi olmamaya karar vermesindeki psikolojik motivasyonlar ve sosyolojik koşullar da uzun zamandır araştırılmaktadır. Houseknecht (1987), çocuk sahibi olmak istemeyen bireylerin bu kararı neden aldıklarının araştıııldığ1 29 çalışmayı incelediği derlemesinde gönüllü çocuksuzluğun çok çeşitli bireysel sebepleri olduğunu ortaya koymuştur. Katılımcılar tarafından en çok bildirilen gerekçeler arasında çocuk bakımı sorumluluğunu almama özgürlüğü, kendine vakit ayırma ile yüksek mobilite için daha çok imkan, daha yüksek evlilik doyumu, kadınların kariyerleri ile ilgili öncelikleri, finansal avantajlar, nüfus artışı ile ilgili endişeler, çocukları genel olarak sevmeme, ebeveynlik yetkinliği ile ilgili endişeler, çocuk doğurmanın fiziksel sonuçları ile ilgili endişeler ve halihazırdaki küresel sorunların olduğu bir dünyaya çocuk getirme ile ilgili kaygılar yer almaktadır.

Daha yakın zamanda yapılan çalışmalarda katılımcılar daha fazla kişisel özgürlüğe sahip olma ve diğer yetişkinlerle daha fazla ilişki kurabilme imkanını (Brooks, 2019; Gillespie, 2003), hayatlarını istedikleri gibi yaşama ve kendi arzu ettikleri şeyleri yapabilmek için daha fazla boş zamana sahip olma firsatını (Ireland, 1993; May, 1995; McAllister ve Clarke, 1998a), partnerlerine ve evliliklerine daha çok vakit ayırma olanağını (Ireland, 1993) çocuk sahibi olmama nedenleri olarak belirtmişlerdir. Nitel bir çalışmada da ebeveynlikle birlikte gelen yaşam tarzı değişikliklerini istememe, annelik rolünü reddetme, kendini ebeveynliğe uygun görmeme veya ebeveyn olmayı istememe gönüllü çocuksuzluğun nedenleri olarak ortaya çıkmıştır (Carmichael ve Whittaker, 2007). Ayrıca evliliklerinin istikrarından emin olmayan (Heaton ve ark., 1999; Silverman ve Silverman, 1971) ve hamileliği ve doğumu travmatik olarak algilayan (Hird ve Abshoff, 2000) çiftler de çocuksuz kalmayı seçebilmektedir.

Bireylerin bilinçli olarak çocuk sahibi olmamayı seçmesinde bazı cinsiyet farkll1ıkları da ortaya çıkmaktadır. Çalışmaların bir kısmında, kadınlar gönüllü çocuksuzluk için daha diğerkam sebepler (örn., dünya nüfusundaki artışla ilgili kaygılar, kendi ebeveynlik yetkinliği ile ilgili şüpheler, pek çok sorunu olan bir dünyaya çocuk getirmeyi iste- 
memek) rapor ederken, erkeklerin daha bireyci gerekçeler (örn., ebeveynliğin finansal yükü, genel olarak çocukları sevmemek) saydıkları ortaya çıkmıştır (Houseknecht, 1987). Öte yandan, kadınların bilinçli olarak çocuk sahibi olmama kararlarında kariyer hedeflerine odaklanma motivasyonunu erkeklere göre daha sık rapor ettiği ise bir başka çalışmanın bulguları arasındadır (Veevers, 1980). Daha yakın zamanda yapılmış bir çalışmada ise gönüllü çocuksuz kadınlar, ebeveynliğin kariyer hedefleri ve boş zaman aktiviteleri ile çeliştiğini, annelik içgüdüsünü ve çocuklara karşı ilgi hissetmediklerini belirtmişlerdir (Park, 2005). Aynı çalışmada gönüllü çocuksuz erkekler, ebeveynliği söz konusu fedakarlıklarda (çoğunlukla finansal olmak üzere) bulunmak istemedikleri için reddettiklerini söylemiştir. Erkekler ayrıca çocuksuz kalma kararını kadınlara göre daha erken ve daha kolay almaktadır (Lunneborg, 2000).

Bunların yanı sıra, kadınlar hiçbir zaman ebeveyn olmak istemediklerini, ebeveyn olmak için doğru ilişki içinde olmadıklarını veya partnerlerinin ebeveyn olmak istemediğini (Graham, Hill, Shelly ve Taket, 2013) ve zaman ve enerjilerini kariyerlerine ayırmak istediklerini (Majumdar, 2004; Somers, 1993) de gönüllü çocuksuzluğun sebepleri arasında saymıştır. Bazı kadınlar, hem annelikte hem de kariyerlerinde başarılı olamayacaklarını düşündükleri için çocuk sahibi olmamaya karar verdiklerini de ifade etmektedir (Gerson, 1986; Ireland, 1993; Morell, 1994). Bununla birlikte, gönüllü çocuksuz kadınların önemli bir kısmı kariyerlerini kimliklerinin temelinde görmediklerini ve yaşamdaki temel doyumu kariyerlerinden değil, kaliteli bir hayat sürmekten aldıklarını rapor etmektedir (McAllister ve Clarke, 1998b). Bu yüzden, çocuk sahibi olmama kararını sadece kariyer odaklı bir yerden açıklamak mümkün görünmemektedir. Ek olarak, anneliğin bireysel kimliklerini yok ettiğini, çocuk sahibi olunduğunda sadece bir anne olarak var olunduğunu düşündükleri ve anneliği bir fedakarlık, görev ve yük olarak gördükleri için çocuksuz kalmayı seçen kadınlar da vardır (Gillespie, 2003; Maher ve Saugeres, 2007; Peterson, 2015). Benzer şekilde, bazı nitel çalışmalarda kadınlar üzerindeki toplumsal baskılara karşı bir feminist duruş olarak anneliğin reddini tercih ettiklerini belirten kadınlar olduğu da görülmüştür (Gillespie, 2003; Ireland, 1993; Morell, 1994). Örneğin, Türkiye'de yapılmış bir nitel çalışmada, çocuksuz kalmayı seçen kadınların toplumun kadınlığı annelik üzerinden inşa etmesine karşı çıktıkları ve anneliği hayat boyu süren ve kendi yaşamlarından bir şeyler alıp götüren bir fedakarlık olarak gördükleri bulunmuştur. Katılımcılar aynı zamanda, ebeveynliğin toplumda kadın ve erkek arasında paylaşılan bir görev değil, sadece anneye yüklenen bir rol olarak gördüklerini ve 
bu rolü üstlenmek istemedikleri için çocuksuz kalmayı tercih ettiklerini de ifade etmişlerdir (Parlak ve Tekin, 2020).

Bu bireysel nedenlerin yanı sıra gönüllü çocuksuzluğun pek çok sosyolojik sebebi de vardır. Bunlar arasında en etkili olanları şüphesiz aile planlaması ve üreme teknolojisindeki son yıllarda yaşanan gelişmeler ve kadınların işgücüne artan katılımıdır (Bartlett, 1995; Campbell, 1985; Chancey ve Dumais, 2009; Gillespie, 2003; Ireland, 1993; McAllister ve Clarke, 1998b). Benzer şekilde, toplumsal değerlerin zaman içinde liberalleşmesi ve geleneksel cinsiyet rollerinin sorgulanmaya başlanması da bireylerin çocuk sahibi olmamaya karar vermesini kolaylaştıran toplumsal faktörler arasında yer almaktadır (Meggiolaro ve Ongaro, 2007). Ayrıca kimi akademisyenler, gönüllü çocuksuzluk oranlarındaki yükselişi sosyal devlet uygulamalarındaki artışla birlikte yaşlılıkta bakım almak için çocuklara muhtaç olma durumunun azalmasına da bağlamaktadır (Park, 2005).

Bireylerin gönüllü çocuksuzluk kararındaki sebepler kadar, bu kararı alırken geçtikleri süreçler de büyük farklılıklar göstermektedir. Bazı kişiler erken yaştan itibaren bilinçli olarak çocuk sahibi olmamaya karar verirken, diğerleri genç yaşlarda ileride belki çocuk sahibi olabileceğini düşünmekte ancak ilerleyen yıllar içinde çocuk sahibi olmadığında ve bunu aslında hiçbir zaman istemediğini fark ettiğinde kendini gönüllü çocuksuz olarak tanımlamaya başlamaktadır (Blackstone ve Stewart, 2012; Gillespie, 1999; Heaton ve ark., 1999; Ireland, 1993; McAllister ve Clarke, 1998a; Morell, 1994). Kimi çiftler kariyerlerinde, ekonomik durumlarında veya evliliklerinde belli bir güvence seviyesine ulaşmayı istemek gibi çeşitli nedenlerden dolayı çocuk sahibi olmayı ertelemekte; bu süre zarfında da çocuksuzluğa alışarak ve sosyal çevrelerinde çocuk bakımının ne kadar zor olduğunu gözlemleyerek çocuk sahibi olmama kararı alabilmektedir (Campbell, 1985). Burada dikkat edilmesi gereken önemli bir nokta, bireylerin çocuksuzlukla ilgili algılarının zaman içinde değişebildiğidir (bkz. Hayfield, Terry, Clarke ve Ellis, 2019). Boylamsal bir çalışmada, katılımcıların \%20'sinin birinci ve ikinci dalga veri toplama arasında çocuk sahibi olmayı isteme konusunda fikir değiştirdiği gözlemlenmiştir (Heaton ve ark., 1999).

Çocuksuz kalmayı seçen çiftlerin, bu kararı nasıl aldığı da önemli bir araştırma sorusudur. Bu konu üzerine yapılan araştırmalar, gönüllü çocuksuzluk kararının genellikle ortak bir biçimde alındığını ortaya koysa da, kadınların bu kararda daha aktif rol oyna- 
dığı da araştırma bulgularına yansımaktadır (Campbell, 1999; Cooper, Cumber ve Hartner, 1978; Gillespie, 2003). Ayrıca partnerlerden biri çocuk sahibi olmak konusunda kararsızsa diğer partnerin net bir şekilde çocuk yapmak istememesi, çiftin çocuksuz olmasında etkili olmaktadır (McAllister ve Clarke, 1998a).

\section{Gönüllü Çocuksuzluğun Sonuçları ve Bu Kararı Alan Bireylerin Karşılaştıkları Olumsuz Kalıpyargılar}

Çocuk sahibi olmanın yaygın norm olduğu ve bilinçli bir şekilde çocuksuz kalmayı tercih etmenin pek çok toplumsal kuralla çeliştiği bir sosyal dünyada, bu kararın bireyler üzerindeki etkileri büyük önem taşımaktadır. Her ne kadar yaygın kanı çocuk sahibi olmamanın pek çok olumsuz sonuç doğuracağı yönünde olsa da, araştırmalar bu varsayımı desteklememektedir (örn., Ganong, Coleman ve Mapes, 1990; Veevers, 1980).

Kimi çalışmalar gönüllü çocuksuz bireylerin yaşam doyumlarının ve iyi oluş hallerinin ebeveyn olanlara göre daha yüksek olduğunu bulurken (Jeffries ve Konnert, 2002; Somers, 1993; Weiss, 1993), diğer çalışmalar bu iki grup arasında anlamlı bir fark olmadığını göstermiştir (Burman ve de Anda, 1985; Callan, 1986, 1987). Benzer şekilde, yaş ve gelir düzeyi istatistiki olarak kontrol edildiğinde gönüllü çocuksuz ve çocuklu bireyler arasında anlamlı bir yaşam doyumu farkı olmadığını ortaya koyulmuştur (Somers, 1993). Bir başka çalışmada çocuksuz kadınların hayatlarındaki özgürlük, esneklik, kişisel mahremiyet ve bağımsızlık düzeylerinden anne olan kadınlara göre daha memnun oldukları bulunmuştur (Callan, 1987). Bu çalışmalar bilinçli bir şekilde çocuk sahibi olmamanın yaşam doyumu üzerinde olumsuz bir etkisi olmadığını, aksine yaşam doyumunu iyileştirici bir etkisinin olabileceğini göstermektedir. Ayrıca pek çok çalışmada gönüllü çocuksuz çiftler, ebeveyn olan çiftlere göre daha yüksek evlilik doyumu rapor etmiştir (Burman ve de Anda, 1985; Callan, 1984, 1986, 1987; Jacobson ve Heaton, 1991; Krishnan, 1993; Monach, 1993; Somers, 1993). Yaygın kanının aksine, çocuksuzluğu seçen insanlar bu kararlarından pişman olmamaktadırlar (Brooks, 2019; Campbell, 1999; Morell, 1994; Somers, 1993).

Çocuk sahibi olmamanın kadınlar için olası tıbbi sonuçları da hayli önemlidir. Kimi araştırmacılar, çocuk doğurmamakla meme kanseri nedeniyle gerçekleşen ölümler arasında bir bağıntı olduğuna işaret etse de (örn., Mettlin, 1999), diğer araştırmacılar bu araştırma sonuçlarının tartışmalı olduğunu ve çocuk sahibi olmayı ertelemenin veya çocuk sahibi olmamanın kısırlık ve çeşitli üreme sistemi kanserlerine yakalanma riskini 
arttırdığına dair sözde tıbbi bulguların kadınların üreme davranışı üzerinde hegemonya kurmak için kullanıldığını iddia etmektedir (Park, 2002; Snitow, 1992).

İleri yaşlarda çocuk sahibi olmayan bireylerin, çocuğu olanlara göre sosyal izolasyon konusunda daha büyük risk altında olduğu bilinmektedir (Gironda, Lubben ve Atchison, 1999; McMullin ve Marshall, 1996). Buna rağmen, gönüllü çocuksuzlar yaşlılıkta da ebeveyn olan akranlarıyla aynı seviyede hayat doyumu ve psikolojik sağlık beyan etmektedir (Beckman ve Houser, 1982; Connidis ve McMullin, 1993; Dykstra ve Keizer, 2009; Houser, Berkman ve Beckman, 1984; McMullin ve Marshall, 1996; Wu ve Hart, 2002). Dahası, bir çalışmada çocuğu olmayan yaşlıların çocuğu olanlara göre daha az stres yaşadığı bulunmuştur (McMullin ve Marshall, 1996). Araştırmalar çocuğu olmayan bireylerin ileri yaşlarda aile üyeleri, arkadaşlar, ait oldukları cemiyetler gibi diğer sosyal destek mekanizmalarına daha çok yatırım yaptıklarını göstermektedir (Albertini ve Kohli, 2009; Wenger, 2009). Tüm bu bulgular gönüllü çocuksuzlukla ilgili yaygın kalıpyargıların aksine, insanların ileri yaşta çocuk sahibi olmadıkları için pişmanlık duymadıklarını, yalnız kalmadıklarını ve mutsuz olmadıklarını; tam tersine hayatlarını sürdürmek için farklı sosyal destek mekanizmalarını devreye sokarak toplumla daha da entegre bir biçimde yaşlandıklarını düşündürmektedir.

Her ne kadar araştırma bulguları gönüllü çocuksuzluğun olumsuz sonuçları olduğunu göstermese de, bilinçli olarak çocuk sahibi olmamayı seçen bireyler bu kararları ile ilgili pek çok olumsuz kalıpyargıya ve sosyal baskıya maruz kalmaktadırlar. Son zamanlarda yaygınlaşan gönüllü çocuksuz hareketi, toplumun ve özellikle iş gücü piyasasının çocuklu bireylere çocuksuz olanlara göre çok daha fazla değer atfettiğini ve kaynak aktardığını; bu şekilde çocuğu olmayan kişilere ayrımcılık uygulandığını öne sürmektedir (örn., Burkett, 2002; Peterson ve Engwall, 2016).

Çocuk sahibi olmak istediği halde tıbbi nedenlerden dolayı ebeveyn olamayan bireyler genellikle sempati ve acıma duygusu ile karşılanırken, toplumun bilinçli bir şekilde çocuksuz kalmayı seçen bireylere karşı tutumları daha olumsuzdur (Callan, 1985; Chancey ve Dumais, 2009; Iverson, Lindsay ve MacInnis, 2020). Çocuk sahibi olmak toplumda "doğal” ve "normal” olarak görülürken, çocuksuz kalma kararı sorgulanması gereken alternatif bir hayat tarzı olarak görülmektedir. Gönüllü çocuksuzlar duygusal olarak dengesiz, sosyal olarak istenmeyen, bencil, bireyci, sorumsuz, maddeci, daha az anaç, daha az olgun, anormal, yakın insan ilişkilerinden yoksun ve mutsuz olarak alg1- 
lanmaktadır (Alexander, Rubinstein, Goodman ve Luborsky, 1992; Campbell, 1985; Carey, Graham, Shelley ve Taket, 2009; Park, 2002; Somers, 1993; Veevers, 1973b). Çocuksuz kadınların anne olamadığı için kadınlık rolünü tamamlayamadıkları düşüncesiyle acımayla karşılandığı da rapor edilmiştir (Blake, 1979; Thomas, 1995). Ayrıca çocuğu olmayan kadınların anne olan kadınlara göre daha az ödüllendirici hayatları olduğu ve hem şimdi hem de gelecekte daha mutsuz olacakları düşünülmektedir (Callan, 1985; Ganong ve ark., 1990; Houseknecht, 1987; Mueller ve Yoder, 1999; Polit, 1978; Veevers, 1980). Dahası, gönüllü çocuksuzları topluma yük olmakla, asalaklıkla ve sosyal devleti kandırmakla suçlayanlar bile vardır (Burkett, 2002). Gönüllü çocuksuzluk üzerine Türkiye'de yapılan bir araştırmada daha cinsiyetçi tutumlara sahip katılımcıların, gönüllü çocuksuz kadınlara karşı daha fazla olumsuz önyargıya sahip olduğu bulunmuştur (Bahtiyar-Saygan ve Sakallı-Uğurlu, 2019). Bu katılımcılar aile olabilmek için mutlaka çocuk sahibi olmanın gerektiği görüşünü de daha çok desteklemişlerdir. Buna ek olarak, daha yüksek eğitim seviyesine sahip ve daha genç insanlar ise gönüllü çocuksuzluğa daha olumlu yaklaştıklarını söylemişlerdir. Benzer şekilde, Kuzey Kıbrıs Türk Cumhuriyeti'nde yapılan başka bir çalışmada da korumacı cinsiyetçiliğin gönüllü çocuksuzluğa yönelik olumsuz tutumları yordadığı bulunmuştur. Ayrıca, dindarlık düzeyi daha yüksek erkeklerin bilinçli olarak çocuk sahibi olmayan insanları daha olumsuz değerlendirdikleri de bu çalışmada ortaya çıkan diğer bir bulgudur (Husnu, 2016).

Öz bildirime dayalı anketlerde ortaya çıkan gönüllü çocuksuzlara yönelik bu olumsuz tutumlar, deneysel çalışmalarda da kendini göstermektedir. Ebeveynler ile çocuksuz bireylerin karşılaştırılmasının istendiği bir çalışmada, katılımcılar fiziksel çekicilik, kaynaklara erişim potansiyeli ve duygusal denge gibi olumlu özelikleri ebeveynlerle daha kolay eşleştirmiştir (Kemkes, 2008). Benzer bir araştırma yöntemi kullanan başka bir çalışmada, ebeveyn olan çiftler gönüllü çocuksuz çiftlere göre daha hassas, sevgi dolu ve psikolojik açıdan sağlıklı olarak algılanmıştır (Jamison, Franzini ve Kaplan, 1979). Çocuk sahibi olma olasılığı düşük değerlendirilen çiftler de, olasıllğı yüksek görülen çiftlere göre daha olumsuz değerlendirilmektedir (Koropeckyj-Cox ve Pendell, 2007). Bir diğer deneysel çalışmada, gönüllü çocuksuzlar ebeveyn olan bireylere göre hem daha mutsuz olarak algılanmış hem de daha çok ahlaki tepki çekmiştir (Ashburn-Nardo, 2017). Türkiye'de yapılan bir araştırmada da ebeveyn olan bireyler, çocuğu olmayanlara göre daha sıcakkanlı ve evliliğinde daha mutlu olarak algılanırken, çocuğu olmayan bireyler daha azimli ama duygusal olarak daha sorunlu olarak değerlendirilmiştir (Çopur ve Koropeckyj-Cox, 2010). 
Gönüllü çocuksuz bireylere karşılaştıkları tepkilerin sorulduğu çalışmalar bu alandaki olumsuz tutumların anlaşılmasında önemli yer tutmaktadır. Bilinçli bir şekilde çocuk sahibi olmamaya karar veren bireyler, toplum tarafindan olumsuz algılandıklarını (Somers, 1993), acıma ve eleştiriyle karşılaştıklarını (Mollen, 2006), işle fazlaca meşgul olmakla suçlandıklarını (Mueller ve Yoder, 1999) ve bencil, soğuk ve maddeci olarak görüldüklerini (Gillespie, 1999; Ireland, 1993; Kelly, 2009; McAllister ve Clarke, 1998a; Morell, 1994; Park, 2002) bildirmişlerdir. Bu alanda gönüllü çocuksuz bireylerle yapılan nitel bir çalışma, gönüllü çocuksuzluğun çocuk sahibi insanlar tarafından kendi seçimlerine karşı bir saldırı olarak algılanarak öfke ile karşılanabildiğini de ortaya koymuştur. Bu çalışmada gönüllü çocuksuz katılımcıların ifadelerinden ortaya çıkan ilginç bir diğer bulgu, çocuk sahibi olan bazı insanların, bilinçli bir şekilde çocuk yapmamayı seçen bireylerle karşılaştıklarında, dünyaya çocuk getirmemenin aslında bir seçenek olduğunu fark ederek kendi tercihlerinden pişmanlık duydukları için gönüllü çocuksuzlara olumsuz tepkiler verebildikleridir (Campbell, 1999).

Bilinçli bir şekilde çocuk sahibi olmamaya karan veren kadınlarla yapılan nitel bir araştırmada, katılımcılar kararlarının şaşkınlık ve yok sayma ile karşılaştığını ve anormal olarak görüldüğünü ifade etmiştir (Gillespie, 2000). Bu çalışmadaki kadınlar, kararlarını paylaştıkları insanların onlara kararlarını ileride değiştireceklerini söylediklerini de belirtmiştir. Bu tepki kararından emin olan kadınlar tarafından son derece rahatsızlık verici ve küçümseyici olarak algılanmaktadır. Özellikle, doktorların çocuk sahibi olmak istemedikleri için kısırlaştırma operasyonu geçirmek isteyen kadınlara "fikrini ileride değiştirirsin" gerekçesiyle tıbbi hizmet vermeyi reddetmesi önemli bir hak ihlali olarak görülmektedir (Campbell, 1999; Gillespie, 2000; Hintz ve Brown, 2019). Ayrıca bilinçli olarak çocuk sahibi olmamayı seçen kadınlar, aynı seçimi yapan erkeklere göre daha çok damgalanmaktadır. (Eicher ve ark., 2016; Lunneborg, 2000; Park, 2002). Bu cinsiyet farklılığı tutum objesinin yanı sıra tutum sahibi noktasında da ortaya çıkmıştır; erkeklerin kadınlara kıyasla gönüllü çocuksuz bireylere karşı daha olumsuz tutumları olduğu bulunmuştur (Koropeckyj-Cox ve Pendell, 2007).

Kadınların gönüllü çocuksuzluğuna karşı bu olumsuz kalıpyargıların bir bileşeninin de toplumda kadınlığın annelik üzerinden inşa edilmesi olduğunun gözden kaçırılmaması gerekmektedir (Gillespie, 2000). Pek çok toplumda hala kadınlığın testi annelik üzerinden yapılmakta ve annelik rolü kadınlara doğal ve sorgulanamaz bir şekilde sosyal, politik, tıbbi ve dini kurumlar üzerinden dayatılmaktadır. Bu nedenle çocuk sahibi 
olmamaya karan veren kadınlar, toplumun kurguladığı kadın kimliğini ve algısını sarstıkları için oldukça katı olumsuz kalıpyargılarla karşılaşmaktadır (Carey ve ark., 2009; Gillespie, 2000; Letherby ve Williams, 1999).

Gönüllü çocuksuzluk alanında yapılan erken dönem akademik çalışmalar bile bu toplumsal yargıları yansıtacak şekilde, çocuk sahibi olmamayı tercih eden kadınların daha maskülen olduğunu iddia etmiştir (Baber ve Dreyer, 1986; Bram, 1984; Callan, 1986). Ancak, yakın dönemde yapılan çalışmalar yaygın toplumsal cinsiyet rolleriyle uyumlu bu çıkarımları sorgulamış ve gönüllü çocuksuzların cinsiyet kimlikleri ve yakın ilişkiler konusundaki tutumlarının toplumun geri kalanının değerlerinden ayrışmadığını göstermiştir (McAllister ve Clarke, 1998b). Çocuk sahibi olmamayı tercih eden kadınlarla yapılan nitel çalışmalar da, bu kadınların kendilerini daha az feminen algılamadıklarını ve anne olmamalarının daha az kadın oldukları anlamına gelmediğini düşündüklerini göstermektedir (Gillespie, 1999, 2000; McAllister ve Clarke, 1998a).

Kadınlığı annelikle bir tutan özcü yaklaşım, çocuk sahibi olsa da olmasa da bütün kadınlar için baskıcıdır (Gandolfo, 2005). Bu yüzden, gönüllü çocuksuzluk kadınlığı annelik üzerinden tanımlayan yaygın kültürel imgeye meydan okumak için bir firsat sağlamaktadır (Gillespie, 2000; Huffer, 1998). Bilinçli bir şekilde çocuk sahibi olmamaya karar veren kadınların bu kararlarını, kadın ve toplumun bir bireyi olmanın tek yolunun anne olmak olmadığını ve anne olmadan da kadın ve toplumun işlevsel bir parçası olunabileceğini anlatarak savunmaları, kadınlığı annelikle eş tutan toplumsal kalıpyargıların zaman içinde değişmesinde önemli rol oynayabilir.

Gönüllü çocuksuzların karşılaştıkları bu olumsuz kalıpyargılar ve sosyal baskılara karşı kullandıkları baş etme stratejileri hayli çeşitlidir. Park'ın (2002) geçiştirme olarak adlandırdığı bir strateji, bireyin kısır olduğunu veya çocuk sahibi olmayı şimdilik ertelediğini söyleyerek gerçek görüşünü saklamasıdır. Bu stratejiyi kullanan bireyler, bilinçli bir şekilde çocuk sahibi olmamaya karar verdiklerini çevrelerine açıklamaktan rahatsız olduklarını, bu yüzden konu açıldığında "belki ileride bir gün" diyerek konuyu geçiştirdiklerini ifade etmektedir (Morell, 1994; Park, 2002). Benzer şekilde, bazı gönüllü çocuksuzlar evlat edinmeyi düşündükleri (Veevers, 1975), çocuk sahibi olmayı eğitim, kariyer veya finansal durumlarıyla ilgili belli bir hedefe ulaşana kadar erteledikleri ya da k1sır oldukları (DeOllos ve Kapinus, 2002; Gillespie, 2000; Park, 2002) gibi kimi bahaneler öne sürerek ve konuyla ilgili gerçek görüşlerini saklayarak toplumsal değerlere uyuyormuş gibi görünmektedir. 
Bahsedilen stratejiyi kullanmayan diğer bireyler ise, daha eğitici bir rol üstlenerek gönüllü çocuksuzların karşılaştığı olumsuz kalıpyargıları kırmaya çalışmaktadır. Örneğin, bu bireyler sosyal çevrelerine herkesin ebeveyn olmak zorunda olmadığını, çocuklara bakım vermenin tek yolunun onları biyolojik olarak dünyaya getirmek olmadığını (örn., akraba ve arkadaşların çocuklarının bakımında rol oynamak) ve dünyaya yeni çocuklar getirmemenin aslında diğerkam bir eylem olduğunu anlatmayı seçebilmektedir (Park, 2002). Ayrıca kimi gönüllü çocuksuz bireyler karşılaştıkları ayrımcılıklara karşı örgütlenmeyi seçmektedir. Bilinçli olarak çocuk sahibi olmamayı seçen bireyler birbirleri ile internet ve sosyal medya üzerinden giderek daha çok iletişime geçmekte ve yaşam stillerinin toplum tarafından kabul görmesi için çaba harcamaktadır (Basten, 2009; Morison, Macleod, Lynch, Mijas ve Shivakumar, 2016).

Diğer yandan, ofansif bir yöntem seçerek ebeveyn olmanın bencilce bir hareket olduğunu iddia eden bireyler de vardır (Park, 2002; Veevers, 1980). Bu kişiler, insanların sadece diğerlerinin onayını almak için ve toplumsal baskı sonucu ebeveyn olduğunu ve çoğunlukla gerçekten istemeyerek çocuk sahibi oldukları için de çocuklarına iyi ebeveynlik yapmadıklarını düşünmektedirler. Bu yüzden de aslında kendilerinin aldığı çocuk sahibi olmama kararının ebeveyn olma kararından daha üstün olduğunu iddia etmektedirler. Benzer şekilde, anneliğe karşı çıkan etik değerler benimsediğini açıkça dile getirmekten çekinmeyen kişiler de mevcuttur (Veevers, 1975). Ayrıca çalışmalar karşılaştıkları yaftalamalarla çocuk sahibi olmanın olumsuz taraflarını vurgulayarak veya işi şakaya vurarak baş eden çocuksuzlar da olduğunu göstermektedir (Morell, 1994). Gönüllü çocuksuzlar, toplumdaki bu onaylamamayı kimi zaman kıskançlığa bağlamaktadır (Veevers, 1980). Bu durum da bir baş etme stratejisi olarak ele alınabilir.

\section{Evrimsel Açıdan Gönüllü Çocuksuzluk}

Üremenin türün devamı için gerekli temel şartlardan biri olduğu düşünüldüğünde, bilinçli bir şekilde çocuk sahibi olmamak ilk bakışta evrimsel açıdan uyumsuz bir strateji olarak görülebilir. Buna dayanarak gönüllü çocuksuzluk olgusunu evrimsel perspektiften anlamaya çalışan bazı araştırmacılar, düşük doğurganlık oranları ve çocuk sahibi olmama davranışlarına yol açarak türün devamı için tehdit oluşturan mekanizmaların aslında paradoksal bir biçimde doğal seçilimin yan ürünleri olarak ortaya çıktığını iddia etmektedir (Aarssen ve Altman, 2006). Doğal seçilim, genleri bir sonraki nesle aktarmay1 garantileyen davranışları seçtiği gibi sembolik ölümsüzlüğü veya geride bir eser b1rakmayı garantileyen davranışları da seçmektedir (Dawkins, 2016). Bundan yola 
ç1karak, Aarssen ve Altman (2006) eğitim ve gelir seviyesi arttıkça, insanların sembolik ölümsüzlüğe ulaşmak ve geride bir eser bırakmak için çocuk sahibi olmaya gerek duymamaya başladığını; iş ve diğer entelektüel faaliyetlerle de bu hedefe ulaşabildiklerini iddia etmektedir. Bu araştırmacılar, bilinçli bir şekilde çocuk sahibi olmamanın evrimsel ihtiyaçları bu şekilde karşılamasından dolayı çocuksuzluğun giderek daha çok insan tarafından tercih edildiğini savunmaktadır. Yine aynı araştırmacılara göre, çocuk sahibi olmak benliğin sadece bir kısmının ölümsüz olmasını sağlarken, somut eserlere imza atmak, keşif ve icatlarda bulunmak, kendi adının toplumda kalıcı olarak yer etmesini sağlamak gibi eylemler benliğin sembolik ölümsüzlüğüne daha fazla ve doğrudan katk1da bulunmaktadır. Buna dayanarak, çocuk büyütmek yerine bu entelektüel faaliyetlerde bulunmanın, gelişmiş toplumlarda bir evrimsel strateji olarak çocuk sahibi olmakla giderek daha çok yarışabilir hale geldiği ve gönüllü çocuksuzluğun bu nedenle artışta olduğu iddia edilmektedir (Aarssen ve Altman, 2006).

Agrillo ve Nelini (2008) çocuk sahibi olmamanın grup için değil, birey (özellikle de kadın) için avantajlı olduğunu vurgulamaktadır. Buna göre, birey ekonomik, fiziksel ve psikolojik kaynaklarını üremeye ve çocuk yetiştirmeye aktarmak yerine kendisi için kullandığında bireysel gelişim, özgürlük ve ekonomik refah bakımından daha avantajlı konuma gelebilir. Elbette, bu avantaj sadece bu strateji belli bir azınlık tarafından uygulandığında sürekli olabilir, zira nüfusun çoğunluğu ürememeyi seçerse türün devamı tehlikeye girecektir.

\section{TARTIŞMA}

Bu derleme çalışmasının amacı, dünyada giderek yükselen bir yaygınlığa sahip olan gönüllü çocuksuzluk olgusunun hem birey hem de toplum için artan önemine dayanarak, bilinçli olarak çocuk sahibi olmama kararının sebeplerini ve sonuçlarını inceleyen araştırmaları sistematik bir şekilde tarayarak Türkçe alan yazına kazandırmaktır. Derleme sonucunda, gönüllü çocuksuzluğu yordayan çeşitli bireysel ve toplumsal faktörleri, bireylerin bu kararı almalarında rol oynayan etmenleri ve karar süreçlerini araştıran pek çok çalışma olduğu ortaya konulmuştur. Ayrıca, gönüllü çocuksuzluğun sonuçları, çocuksuz kalmaya karar veren bireylerin karşılaştıkları olumsuz kalıpyargılar ve bunlarla baş etme stratejilerinin de detaylıca araştırıldığı pek çok çalışma olduğu gösterilmiştir.

$\mathrm{Bu}$ çalışmalar, gönüllü çocuksuzluğun farklı kişiler için farklı faktörlerden etkilenerek karmaşık bir mekanizmayla ortaya çıkan bir sosyal olgu olduğunu göstermektedir 
(örn., Agrillo ve Nelini, 2008; Blackstone ve Stewart, 2012; Shapiro, 2014). Bilinçli olarak çocuk sahibi olmamaya karar veren kişiler demografik olarak birbirlerine belli ölçüde benzese de, bu kararı alma gerekçelerinin, mekanizmalarının ve kararları ile yaşama süreçlerinin hayli çeşitli olduğu anlaşılmaktadır.

Bireyler, sosyoekonomik konumları iyileştikçe (örn., Abma ve Martinez, 2006; Somers, 1993), iş gücüne daha çok katılıp, kariyerlerine daha çok önem verdikçe (örn., Cwikel ve ark., 2006; Park, 2002) ve daha liberal değerler benimsedikçe (örn., Avison ve Furnham, 2015; Burman ve de Anda, 1985) çocuk sahibi olmama kararı alabilmektedir. İş ve benzeri entelektüel faaliyetlerin sembolik ölümsüzlük ve geride eser bırakma gibi evrimsel ihtiyaçları dünyaya çocuk getirmekle yarışır düzeyde karşılamaya başlamasıyla beraber, gönüllü çocuksuzluk gelişmiş ülkelerde giderek daha yaygın şekilde gözlemlenmektedir (Aarssen ve Altman, 2006). Bu açıdan bakıldığında, hem finansal hem de ilişki/yaşam doyumu gibi psikolojik açılardan avantajlı olabilen çocuksuzluk kararının aslında sınıfsal bir boyutu olduğu görülmektedir. Gönüllü çocuksuzluğun ancak toplumun azınlığı tarafından benimsendiğinde biyolojik evrim bakımından tehlikesiz olacağı göz önüne alındığında, bu kararı verebilme özgürlüğünün sosyal statüyle beraber artması sosyal evrim bakımından ilginçtir. Ayrıca, sürekli gelişen doğum kontrol tekniklerinin, üreme teknolojilerinin ve bazı toplumlarda liberal değerlerin giderek daha çok benimsenmesinin bu olgunun yaygınlaşmasına katkıda bulunduğu da ileri sürülebilir. İlerleyen yıllarda tüm bu faktörlerin yaygınlığının artma olasılığı, çocuk sahibi olmamayı seçen bireylerin sayısında da bir artış olabileceğini düşündürmektedir.

Çocuk sahibi olmak kadar olmamak da bireylerin özgür iradesine bırakılması gereken bir karardır ve toplumda çocuk sahibi olmayı seçen bireylere destek verildiği gibi bunu seçmeyen bireylere de destek verilmelidir. Bu hem bireylerin hayatlarına istedikleri gibi yön verme haklarını korumak bakımından önemlidir, hem de çocuk sahibi olan insanların buna isteyerek karar vermesi ve böylece çocuklarına daha iyi ebeveynlik yapma olasılıklarının artırmasını sağlamak bakımından toplumsal düzeyde faydalıdır. $\mathrm{Bu}$, hem kadınların hem de erkeklerin özgürleşmesiyle ve çocukların aldığı bakımın kalitesinin artmasıyla birlikte toplumun refahını da artırabilecek bir stratejidir. Elbette bu hususun önemli bir parçası doğum kontrolü ve kürtaja sağlıklı erişimin sağlanmasıdır. Alan yazındaki çalışmalar toplumların bu noktadan çok uzak olduğunu göstermektedir. Çocuk sahibi olmamayı seçen bireyler çok çeşitli olumsuz kalıpyargılarla karşılaşmak- 
ta; kimi zaman acıma ve küçümseme, kimi zaman da öfke ile yüzleşmektedir (örn., Campbell, 1999; Mollen, 2006; Park, 2002; Somers, 1993). Bunun sonucu olarak gönüllü çocuksuzlar çoğunlukla ya gerçek görüşlerini gizleme ihtiyacı hissetmekte ya da kendi kararlarının ebeveynlikten daha üstün olduğunu iddia ederek atağa geçmek zorunda kalmaktadır (örn., Gillespie, 2000; Park, 2002; Veevers, 1980). Çocuk sahibi olmama kararının, çocuk sahibi olma kararı kadar doğal bir hak olduğunun ve bu kararı alan insanların hala toplumun işlevsel parçaları olabileceğinin sabırla anlatılması olumsuz kalıpyargıların zaman içinde kırılması için faydalı olabilir. Bütün bu yaftalamalara rağmen, araştırmalar çocuk sahibi olmamayı seçen bireylerin yaşam doyumu ve psikolojik sağlık bakımından ebeveyn olanlardan yaşam boyunca farklılaşmadığını göstermektedir (örn., Dykstra ve Keizer, 2009; McMullin ve Marshall, 1996; Wu ve Hart, 2002). Ayrıca yaygın kanının aksine çocuksuz kalmak pişmanlığa yol açıyor gibi görünmemektedir (örn., Brooks, 2019).

Gönüllü çocuksuzluğu inceleyen çok sayıdaki çalışmayla alan yazın hayli zengin olsa da ileride yapılacak çalışmaların dikkate alması gereken pek çok husus bulunmaktadır. Bu hususlardan belki de en önemlisi, çocuksuz bireylerin hangileri için bu durumunun kendi bilinçli tercihleri sonucu ve hangileri için kontrollerinde olmayan dişsal faktörlerin sonucu olarak ortaya çıktığının daha net olarak araştırılmasıdır. Alan yazında hali hazırdaki bazı çalışmalar tarafından (örn., Biddlecom ve Martin, 2006; Dye, 2008; Paul, 2001), çocuksuz bireyler tek bir kategori altında incelenmekte, bu yüzden de gönüllü ve gönülsüz çocuksuzluk arasındaki önemli farklar kaçırılmaktadır. Gelecek çalışmaların üzerine eğilmesinin şüphesiz çok önemli olduğu bir diğer alan da, yıllar içinde artış gösteren gönüllü çocuksuzluk kararının toplumların demografik yapısını ve hem var olan çocuklara hem de çocuksuz yaşlanan bireylere verilen bakımı nasıl etkileyebileceğidir. Gelecek öngörüleri yapacak böyle çalışmalar devletlerin ve özel kurumların politikalarını düzenlemeleri için çok yararlı olabilir. Ayrıca çocuk sahibi olmamanın tıbbi sonuçlarının, güvenilirliği yüksek çalışmalarla net olarak ortaya konması gönüllü çocuksuzluğun kişilerin sağlığı üzerinde etkisi olduğuna dair tartışmaların bilimsel yolla çözüme kavuşması bakımından gereklidir. Buradan elde edilecek güvenilir bilimsel sonuçlar, hem insanların eğer ihtiyaç varsa uygun sağlık önlemlerini alması hem de gönüllü çocuksuzlara yönelik olumsuz kalıpyargıların aşılması için değerli olacaktır. Ayrıca gönüllü çocuksuzluk kararının alınabilmesinde toplumsal cinsiyet rollerinin ve geleneksel aile modelinin önemli rolü olduğu düşünüldüğünde, farklı toplumların değerlerini 
karşılaştıran kültürlerarası çalışmaların alan için ne kadar önemli olduğu anlaşılabilir. Diğer bir deyişle, bu alanda kültürler arası çalışmalara ihtiyaç vardır. Son olarak, ileride yapılacak çalışmaların bilinçli olarak çocuk sahibi olmamaya karar veren bireylerin özellikle internet ve sosyal medya üzerinden örgütlenerek seslerini nasıl daha duyulur hale getireceğini ve bu kolektif eylemlerin sonuçlarını incelemesi, gönüllü çocuksuzluğun bir sosyal hareket haline gelip gelmeyeceğinin anlaşılması açısından bilgi verici olabilir. Bununla bağlantılı olarak, toplumda giderek yaygınlaşan "çocuklu aile dostu" (örn., kimi işletmelerin çocuklu ailelere indirim yapması, kimi iş yerlerinin çocuğu olan bireylere daha az sorumluluk vermesi) uygulamaların çocuksuz bireyler tarafindan nasıl algılandığını ve bu bireylerin çocuklu bireylerle eşit haklara sahip olmak için vereceği mücadeleyi incelemek büyük önem taşımaktadır.

Gelecek çalışmalar tasarlanırken dikkat edilmesi faydalı olacak pek çok yöntemsel husus vardır. Gönüllü çocuksuzluk üzerine yapılan çalışmaların büyük çoğunluğunun ilişkisel olması alan yazındaki önemli eksikliklerden biridir. Her ne kadar alanda yapılmış nitel çalışmalar bulunsa da derinlemesine görüşmelerle daha iyi anlaşılabilecek pek çok araştırma sorusu hala mevcuttur. Bilinçli olarak çocuk sahibi olmamaya karar veren bireylerle ileride yapılacak başka nitel çalışmalar, insanların gönüllü çocuksuzluk kararını hangi mekanizmalarla aldıklarının daha iyi anlaşılması için faydalı olabilir. Bu çalışmaların katılımcılara gönüllü çocuksuzluk kararına giden yolda hangi faktörleri göz önüne aldığını, hangilerine önem vermediğini net bir şekilde sormalıdır. Ayrıca bireylerin aile kavramını ve toplumsal cinsiyet kimliklerini algılama biçimlerinin gönüllü çocuksuzluk kararlarında nasıl bir rol oynadığının nitel çalışmalarla araştırılması zengin bilgiler ortaya çıkarabilir.

Gönüllü çocuksuzluk üzerine yapılan çalışmaların katılımcıları ağırlıklı olarak heteroseksüel ve evli kadınlardır (örn., Mollen, 2006; Mueller ve Yoder, 1999; Park, 2005). Alandaki araştırmaların çok az bir bölümü erkeklerin bu konudaki tutum ve davranışları hakkında fikir vermektedir (örn., Houseknecht, 1987; Lunneborg, 2000; Park, 2005; Veevers, 1980), bu durum da hem gönüllü çocuksuzluk konusunun ağırlıklı olarak kadınlar üzerinden ele alınmasına sebep olmakta, hem de çocuk sahibi olmama kararının kadınlar ve erkekler açısından nasıl farklılaştığını anlamayı zorlaştırmaktadır. Bu yüzden ileride yapılacak çalışmaların örneklemlerine kadınların yanı sıra erkeklerin de dahil etmesi çok kritiktir. Ayrıca, bekar kadınlar ve homoseksüel çiftlerle yapılacak gelecek çalışmalar çocuk sahibi olmama kararının daha bütüncül olarak ele alınabilmesi için 
gereklidir, zira bu popülasyonlar şimdiye kadar yapılan çalışmalarda hiç temsil edilmemiştir. Gelecek çalışmaların daha temsili örneklemlerle yapılması, farklı kimlikleri olan bireylerin gönüllü çocuksuzluk kararı almalarındaki olası farklı mekanizmaların anlaşılması açısından özellikle önem taşımaktadır. Alan yazındaki bir diğer eksiklik de, gönüllü çocuksuzlara yönelik tutumları araştıran çalışmaların büyük bir kısmının henüz ebeveynlik kararından uzak olan üniversite öğrencileri ile yapılmış olmasıdır. İleride bu konuda yapılacak çalışmaların temsili örneklemler kullanması, gönüllü çocuksuzluğa yönelik toplumdaki tutumların daha doğru bir şekilde anlaşılması için önemlidir. Dikkat edilmesi gereken bir diğer yöntemsel husus da gönüllü çocuksuzluk üzerine yapılan çalışmalarda genel olarak insanlara neden çocuk sahibi olmadıklarının soruluyor olmasıdır. Diğer taraftan, ebeveyn olan bireylerin neden çocuk sahibi olmaya karar verdikleri alan yazında nadiren sorgulanmaktadır. Alanda çalışan akademisyenlerin bu yanlılığın farkında olması, gönüllü çocuksuzluğun doğaldan sapan "anormal” bir durum olduğu algısının kırılması için önem taşımaktadır.

Sonuç olarak, birey ve toplum için çok kritik sonuçları olan gönüllü çocuksuzluk, üzerinde daha fazla araştırma yapılması gereken ve hem araştırmacılar hem de uygulamacılar için önem taşıyan bir olgudur. Yaygınlığı giderek artan çocuksuz kalma kararı hem bireysel özgürlüklerin korunması, hem de toplumların demografik yapılarının sağlıklı bir şekilde yapılandırılması açısından önem teşkil etmektedir. Buna ek olarak, çocuk ve yaşlılara en iyi şekilde bakım verilmesinin sağlanması için üzerinde hassasiyetle durulması gereken sosyal bir gerçekliktir.

Teşekkür: Makalenin yazım ve dil bakımından kontrolünü yapan Sevinç Laleli’ye çok teşekkür ederim.

\footnotetext{
Hakem Değerlendirmesi: Dış bağımsız.

Çıkar Çatışması: Yazar çıkar çatışması bildirmemiştir.

Finansal Destek: Yazar bu çalışma için finansal destek almadığını beyan etmiştir.

Peer-review: Externally peer-reviewed.

Conflict of Interest: The author has no conflict of interest to declare.

Grant Support: The author declared that this study has received no financial support.
} 


\section{Kaynakça/References}

Aarssen, L. W. ve Altman, S. T. (2006). Explaining below-replacement fertility and increasing childlessness in wealthy countries: Legacy drive and the "Transmission Competition" Hypothesis. Evolutionary Psychology, 4(1), 290-302. doi:10.1177/147470490600400125

Abma, J. C., Chandra, A., Mosher, W. ve Peterson, L. (1998). Fertility, family planning, and women's health: New data from the 1995 National Survey of Family Growth. Pennsylvania: Diane Publishing.

Abma, J. C. ve Martinez, G. M. (2006). Childlessness among older women in the United States: Trends and profiles. Journal of Marriage and Family, 68(4), 1045-1056. doi:10.1111/j.17413737.2006.00312.x

Agrillo, C. ve Nelini, C. (2008). Childfree by choice: A review. Journal of Cultural Geography, 25(3), 347-363. doi:10.1080/08873630802476292

Albertini, M. ve Kohli, M. (2009). What childless older people give: Is the generational link broken? Ageing and Society, 29(8), 1261-1274. doi:10.1017/S0144686X0999033X

Alexander, B. B., Rubinstein, R. L., Goodman, M. ve Luborsky, M. (1992). A path not taken: A cultural analysis of regrets and childlessness in the lives of older women. The Gerontologist, 32(5), 618626. doi:10.1093/geront/32.5.618

Ashburn-Nardo, L. (2017). Parenthood as a moral imperative? Moral outrage and the stigmatization of voluntarily childfree women and men. Sex Roles, 76(5-6), 393-401. doi:10.1007/s11199-016-0606-1

Avison, M. ve Furnham, A. (2015). Personality and voluntary childlessness. Journal of Population Research, 32(1), 45-67. doi:10.1007/s12546-014-9140-6

Baber, K. M. ve Dreyer, A. S. (1986). Gender-role orientations in older child-free and expectant couples. Sex Roles, 14(9-10), 501-512.

Bachu, A. (1999). Is childlessness among American women on the rise? Suitland: Population Division, US Bureau of the Census.

Bahtiyar-Saygan, B. ve Sakalli-Uğurlu, N. (2019). Development of attitudes toward voluntary childlessness scale and its associations with ambivalent sexism in Turkey. Journal of Family Issues, 40(17), 2499-2527. doi:10.1177/0192513X19860168

Bartlett, J. (1995). Will you be mother? Women who choose to say no. London: Virago Press.

Basten, S. (2009). Voluntary childlessness and being childfree. The future of human reproduction: Working paper, Vienna Institute of Demography, 5, 1-23.

Beckman, L. J. ve Houser, B. B. (1982). The consequences of childlessness on the social-psychological well-being of older women. Journal of Gerontology, 37(2), 243-250. doi:10.1093/geronj/37.2.243

Biddlecom, A. ve Martin, S. (2006). Childless in America. Contexts, 5(4), 54-54.

Blackstone, A. ve Stewart, M. D. (2012). Choosing to be childfree: Research on the decision not to parent. Sociology Compass, 6(9), 718-727. doi:10.1111/j.1751-9020.2012.00496.x

Blake, J. (1979). Is zero preferred? American attitudes toward childlessness in the 1970s. Journal of Marriage and the Family, 41(2), 245-257. doi:10.2307/351694

Bowlby, J. (1973). Attachment and loss: Vol. II. Separation: Anxiety and anger. New York: Basic Books.

Bowlby, J. (1980). Attachment and loss: Vol. III. Loss: Sadness and depression. New York: Basic Books.

Bowlby, J. (1982). Attachment and loss: Vol. I. Attachment (Gözden geçirilmiş basım). New York: Basic Books. (Orjinal basim 1969).

Bram, S. (1984). Voluntarily childless women: Traditional or nontraditional? Sex Roles, 10(3-4), 195206. 
Brooks, C. (2019). Meaning-making among intentionally childless women. International Journal of Transpersonal Studies, 38(1), 140-153. doi:10.24972/ijts.2019.38.1.140

Burkett, E. (2002). The baby boon: How family-friendly America cheats the childless. New York: Free Press.

Burman, B. ve de Anda, D. (1985). Parenthood or nonparenthood: A comparison of intentional families. Lifestyles, 8(2), 69-84.

Callan, V. J. (1984). Childlessness and marital adjustment. Australian Journal of Sex, Marriage and Family, 5(4), 210-214.

Callan, V.J.(1985). Perceptions of parents, the voluntarily and involuntarily childless: Amultidimensional scaling analysis. Journal of Marriage and the Family, 47(4), 1045-1050. doi:10.2307/352349

Callan, V. J. (1986). Single women, voluntary childlessness and perceptions about life and marriage. Journal of Biosocial Science, 18(4), 479-487. doi:10.1017/S0021932000016497

Callan, V. J. (1987). The personal and marital adjustment of mothers and of voluntarily and involuntarily childless wives. Journal of Marriage and the Family, 49(4), 847-856. doi:10.2307/351978

Campbell, A. (1999). Childfree and sterilized: Women's decisions and medical responses. London: Cassell.

Campbell, E. (1985). The childless marriage: An exploratory study of couples who do not want children. London: Tavistock.

Carey, G. E., Graham, M., Shelley, J. ve Taket, A. (2009). Discourse, power and exclusion: The experiences of childless women. A. Taket, B. R. Crisp, A. Neill, G. Lamaro, M. Graham ve S. Barter-Godfrey (Ed.), Theorising social exclusion içinde (ss. 127-133). New York: Routledge.

Carmichael, G. A. ve Whittaker, A. (2007). Choice and circumstance: Qualitative insights into contemporary childlessness in Australia. European Journal of Population, 23(2), 111-143. doi:10.1007/s10680-006-9112-4

Chancey, L. ve Dumais, S. A. (2009). Voluntary childlessness in marriage and family textbooks, 1950 - 2000. Journal of Family History, 34(2), 206-223. doi:10.1177/0363199008330733

Connidis, I. A. ve McMullin, J. A. (1993). To have or have not: Parent status and the subjective wellbeing of older men and women. The Gerontologist, 33(5), 630-636. doi:10.1093/geront/33.5.630

Cooper, P. E., Cumber, B. ve Hartner, R. (1978). Decision-making patterns and postdecision adjustment of childfree husbands and wives. Alternative Lifestyles, 1(1), 71-94.

Crispell, D. (1993). Planning no family, now or ever. American Demographics, 15(10), 23-24.

Cwikel, J., Gramotnev, H. ve Lee, C. (2006). Never-married childless women in Australia: Health and social circumstances in older age. Social Science \& Medicine, 62(8), 1991-2001. doi:10.1016/j. socscimed.2005.09.006

Çopur, Z. ve Koropeckyj-Cox, T. (2010). University students' perceptions of childless couples and parents in Ankara, Turkey. Journal of Family Issues, 31(11), 1481-1506. doi:10.1177/0192513X10361577

Dawkins, R. (2016). The selfish gene. Oxford: Oxford University Press.

DeOllos, I. Y. ve Kapinus, C. A. (2002). Aging childless individuals and couples: Suggestions for new directions in research. Sociological Inquiry, 72(1), 72-80.

Dye, J. L. (2008). Fertility of American women: 2006. Current Population Reports, US Census Bureau, 20, 1-22.

Dykstra, P. A. ve Keizer, R. (2009). The wellbeing of childless men and fathers in mid-life. Ageing and Society, 29(8), 1227-1242. doi:10.1017/S0144686X08008374

Eicher, V., Settersten, R. A., Penic, S., Glaeser, S., Martenot, A. ve Spini, D. (2016). Normative climates of parenthood across Europe: Judging voluntary childlessness and working parents. European Sociological Review, 32(1), 135-150. doi:10.1093/esr/jcv083 
Gandolfo, E. (2005). A lesser woman? Fictional representations of the childless woman. A. O'Reilly, M. Porter ve P. Short (Ed.), Motherhood: Power \& oppression içinde (ss. 111-123). Toronto: Women's Press.

Ganong, L. H., Coleman, M. ve Mapes, D. (1990). A meta-analytic review of family structure stereotypes. Journal of Marriage and the Family, 52(2), 287-297. doi:10.2307/353026

Gerson, K. (1986). Hard choices: How women decide about work, career and motherhood. Berkeley: University of California Press.

Gillespie, R. (1999). Voluntary childlessness in the United Kingdom. Reproductive Health Matters, 7(13), 43-53.

Gillespie, R. (2000). When no means no: Disbelief, disregard and deviance as discourses of voluntary childlessness. Women's Studies International Forum, 23(2), 223-234. doi:10.1016/S02775395(00)00076-5

Gillespie, R. (2003). Childfree and feminine: Understanding the gender identity of voluntarily childless women. Gender \& Society, 17(1), 122-136. doi:10.1177/0891243202238982

Gironda, M., Lubben, J. E. ve Atchison, K. A. (1999). Social networks of elders without children. Journal of Gerontological Social Work, 31(1-2), 63-84.

Graham, M., Hill, E., Shelly, J. ve Taket, A. (2013). Why are childless women childless? Findings from an exploratory study in Victoria, Australia. Journal of Social Inclusion, 4(1), 70-89. doi:10.36251/josi.63

Hayfield, N., Terry, G., Clarke, V. ve Ellis, S. (2019). "Never Say Never?” Heterosexual, bisexual, and lesbian women's accounts of being childfree. Psychology of Women Quarterly, 43(4), 526-538. doi: $10.1177 / 0361684319863414$

Hazan, C. ve Shaver, P. (1987). Romantic love conceptualized as an attachment process. Journal of Personality and Social Psychology, 52(3), 511-524. doi:10.1037/0022-3514.52.3.511

Heaton, T. B., Jacobson, C. K. ve Fu, X. N. (1992). Religiosity of married couples and childlessness. Review of Religious Research, 33(3), 244-255.

Heaton, T. B., Jacobson, C. K. ve Holland, K. (1999). Persistence and change in decisions to remain childless. Journal of Marriage and the Family, 61(2), 531-539. doi:10.2307/353767

Hintz, E. A. ve Brown, C. L. (2019). Childfree by choice: Stigma in medical consultations for voluntary sterilization. Women's Reproductive Health, 6(1), 62-75. doi:10.1080/23293691.2018.1556427

Hird, M. J. ve Abshoff, K. (2000). Women without children: A contradiction in terms? Journal of Comparative Family Studies, 31(3), 347-366. doi:10.3138/jcfs.31.3.347

Houseknecht, S. K. (1987). Voluntary childlessness. S. K. Steinmetz ve M. B. Sussman (Ed.), Handbook of marriage and the family içinde (ss. 369-395). New York: Plenum Press.

Houser, B. B., Berkman, S. L. ve Beckman, L. J. (1984). The relative rewards and costs of childlessness for older women. Psychology of Women Quarterly, 8(4), 395-398. doi:10.1111/j.1471-6402.1984.tb00647.x

Huffer, L. (1998). Maternal pasts, feminist futures: Nostalgia, ethics, and the question of difference. Standford: Stanford University Press.

Husnu, S. (2016). The role of ambivalent sexism and religiosity in predicting attitudes toward childlessness in Muslim undergraduate students. Sex Roles, 75(11-12), 573-582. doi:10.1007/ s11199-016-0639-5

Ireland, M. S. (1993). Reconceiving women: Separating motherhood from female identity. New York: Guilford Press.

Iverson, H., Lindsay, B. ve MacInnis, C. C. (2020). You don't want kids?!: Exploring evaluations of those without children. The Journal of Social Psychology, 160(5), 719-733. doi:10.1080/0022454 5.2020 .1742080 
Jacobson, C. K. ve Heaton, T. B. (1991). Voluntary childlessness among American men and women in the late 1980's. Social Biology, 38(1-2), 79-93. doi:10.1080/19485565.1991.9988773

Jamison, P. H., Franzini, L. R. ve Kaplan, R. M. (1979). Some assumed characteristics of voluntarily childfree women and men. Psychology of Women Quarterly, 4(2), 266-273. doi:10.1111/j.1471-6402.1979.tb00714.x

Jeffries, S. ve Konnert, C. (2002). Regret and psychological well-being among voluntarily and involuntarily childless women and mothers. The International Journal of Aging and Human Development, 54(2), 89-106. doi:10.2190/J08N-VBVG-6PXM-0TTN

Kagitcibasi, C. ve Ataca, B. (2015). Value of children, family change, and implications for the care of the elderly. Cross-Cultural Research, 49(4), 374-392. doi:10.1177/1069397115598139

Keizer, R., Dykstra, P. A. ve Jansen, M. D. (2008). Pathways into childlessness: Evidence of gendered life course dynamics. Journal of Biosocial Science, 40(6), 863-878. doi:10.1017/S0021932007002660

Kelly, M. (2009). Women's voluntary childlessness: A radical rejection of motherhood? Women's Studies Quarterly, 37(3/4), 157-172. doi:10.1353/wsq.0.0164

Kemkes, A. (2008). Is perceived childlessness a cue for stereotyping? Evolutionary aspects of a social phenomenon. Biodemography and Social Biology, 54(1), 33-46. doi:10.1080/19485565.2008.998 9130

Koropeckyj-Cox, T. ve Pendell, G. (2007). The gender gap in attitudes about childlessness in the United States. Journal of Marriage and Family, 69(4), 899-915. doi:10.1111/j.1741-3737.2007.00420.x

Krishnan, V. (1993). Religious homogamy and voluntary childlessness in Canada. Sociological Perspectives, 36(1), 83-93. doi:10.2307/1389443

Letherby, G. ve Williams, C. (1999). Non-motherhood: Ambivalent autobiographies. Feminist Studies, 25(3), 719-728. doi:10.2307/3178673

Llewellyn, D. (2016). Maternal silences: Motherhood and voluntary childlessness in contemporary Christianity. Religion and Gender, 6(1), 64-79. doi:10.18352/rg.10131

Lunneborg, P. W. (2000). The chosen lives of childfree men. New York: Bergin and Garvey.

Maher, J. ve Saugeres, L. (2007). To be or not to be a mother? Women negotiating cultural representations of mothering. Journal of Sociology, 43(1), 5-21. doi:10.1177/1440783307073931

Majumdar, D. (2004). Choosing childlessness: Intentions of voluntary childlessness in the United States. Michigan Sociological Review, 18, 108-135.

Martinez, G., Daniels, K., Chandra, A. ve Division of Vital Statistics (2012). Fertility of men and women aged 15-44 years in the United States: National Survey of Family Growth, 2006-2010. National Health Statistics Report, 51, 1-29.

May, E. T. (1995). Barren in the promised land: Childless Americans and the pursuit of happiness. New York: Basic Books.

McAllister, F. ve Clarke, L. (1998a). Choosing childlessness. London: Family Policy Studies Centre.

McAllister, F. ve Clarke, L. (1998b). A study of childlessness in Britain. Family Policy Studies Centre, Joseph Rowntree Foundation.

McMullin, J. A. ve Marshall, V. W. (1996). Family, friends, stress, and well-being: Does childlessness make a difference? Canadian Journal on Aging / La Revue Canadienne du Vieillissement, 15(3), 355-373. doi:10.1017/S0714980800005821

Meggiolaro, S. ve Ongaro, F. (2007). Choosing to be childfree: Individual and contextual factors. Rivista di Studi Familiari. Special Issue: Childfree, 12(1), 57-70.

Mettlin, C. (1999). Global breast cancer mortality statistics. CA: A Cancer Journal for Clinicians, 49(3), 138-144. 
Mollen, D. (2006). Voluntarily childfree women: Experiences and counseling considerations. Journal of Mental Health Counseling, 28(3), 269-282. doi:10.17744/mehc.28.3.39w5h93mreb0mk4f

Monach, J. H. (1993). Childless: No choice: The experience of involuntary childlessness. London: Routledge.

Morell, C. M. (1994). Unwomanly conduct: The challenges of intentional childlessness. New York: Routledge.

Morison, T., Macleod, C., Lynch, I., Mijas, M. ve Shivakumar, S. T. (2016). Stigma resistance in online childfree communities: The limitations of choice rhetoric. Psychology of Women Quarterly, 40(2), 184-198. doi:10.1177/0361684315603657

Mosher, W. D., Williams, L. B. ve Johnson, D. P. (1992). Religion and fertility in the United States: New patterns. Demography, 29(2), 199-214. doi:10.2307/2061727

Mueller, K. A. ve Yoder, J. D. (1999). Stigmatization of non-normative family size status. Sex Roles, 41(11-12), 901-919. doi:10.1023/A:1018836630531

Newport, F. ve Wilke, J. (2013). Desire for children still norm in US. Gallup. Erişim adresi: https:// news.gallup. com/poll/164618/desire-children-norm.aspx.

Park, K. (2002). Stigma management among the voluntarily childless. Sociological Perspectives, 45(1), 21-45. doi:10.1525/sop.2002.45.1.21

Park, K. (2005). Choosing childlessness: Weber's typology of action and motives of the voluntarily childless. Sociological Inquiry, 75(3), 372-402. doi:10.1111/j.1475-682X.2005.00127.x

Parlak, S. ve Tekin, I. (2020). A phenomenological study on voluntarily childless women. Psikoloji Çalışmaları / Studies in Psychology, 161-186. doi:10.26650/SP2019-0034

Paul, P. (2001). Childless by choice. American Demographics, 23(11), 44-50.

Peterson, H. (2015). Fifty shades of freedom. Voluntary childlessness as women's ultimate liberation. Women's Studies International Forum, 53, 182-191. doi:10.1016/j.wsif.2014.10.017

Peterson, H. ve Engwall, K. (2016). Missing out on the parenthood bonus? Voluntarily childless in a "child-friendly" society. Journal of Family and Economic Issues, 37(4), 540-552. doi:10.1007/ s10834-015-9474-z

Polit, D. F. (1978). Stereotypes relating to family-size status. Journal of Marriage and the Family, 40(1), 105-114. doi:10.2307/350612

Sappleton, N. (2018). Introduction: Childlessness through a feminist lens. N. Sappleton (Ed.), Voluntary and involuntary childlessness: The joys of otherhood? içinde (ss. 1-7). United Kingdom: Emerald Publishing.

Seccombe, K. (1991). Assessing the costs and benefits of children: Gender comparisons among childfree husbands and wives. Journal of Marriage and the Family, 53(1), 191-202. doi:10.2307/353143

Shapiro, G. (2014). Voluntary childlessness: A critical review of the literature. Studies in the Maternal, 6(1), 1-15. doi:10.16995/sim.9

Silverman, A. ve Silverman, A. (1971). The case against having children. New York: David McKay Company.

Snitow, A. (1992). Feminism and motherhood: An American reading. Feminist Review, 40, 32-51. doi: $10.2307 / 1395276$

Somers, M. D. (1993). A comparison of voluntarily childfree adults and parents. Journal of Marriage and the Family, 55(3), 643-650. doi:10.2307/353345

Thomas, I. M. (1995). Childless by choice. Hispanic, 8(4), 50-53.

Türkiye İstatistik Kurumu. (2020). Doğum İstatistikleri. Erişim adresi: http://tuik.gov.tr/PreTablo. do?alt_id $=1060$ 
Veevers, J. E. (1973a). Voluntarily childless wives: An exploratory study. Sociology and Social Research, 57(3), 356-366.

Veevers, J. E. (1973b). Voluntary childlessness: A neglected area of family study. The Family Coordinator, 22(2), 199-205. doi:10.2307/582108

Veevers, J. E. (1975). The moral careers of voluntarily childless wives: Notes on the defense of a variant world view. The Family Coordinator, 24(4), 473-487. doi:10.2307/583032

Veevers, J. E. (1979). Voluntary childlessness: A review of issues and evidence. Marriage \& Family Review, 2(2), 1-26. doi:10.1300/J002v02n02_01

Veevers, J. E. (1980). Childless by choice. Toronto: Butterworths.

Weiss, R. (1993). The kidless culture. Health, 7(4), 40-42.

Wenger, G. C. (2009). Childlessness at the end of life: Evidence from rural Wales. Ageing and Society, 29(8), 1243-1259. doi:10.1017/S0144686X09008381

Wu, Z. ve Hart, R. (2002). The mental health of the childless elderly. Sociological Inquiry, 72(1), 21-42. doi:10.1111/1475-682X.00004

Zelizer, V. (1985). Pricing the priceless child. Princeton, NJ: Princeton University Press. 
